J. Dairy Sci. 92:826-836

doi:10.3168/jds.2008-1531

(C) American Dairy Science Association, 2009.

\title{
Hot topic: Changes in angiotensin-converting enzyme inhibition and concentrations of the tripeptides Val-Pro-Pro and Ile-Pro-Pro during ripening of different Swiss cheese varieties
}

\author{
J. Meyer, U. Bütikofer, B. Walther, D. Wechsler, ${ }^{1}$ and R. Sieber \\ Agroscope Liebefeld-Posieux Research Station ALP, Schwarzenburgstrasse 161, 3003 Bern, Switzerland
}

\begin{abstract}
The angiotensin-converting enzyme (ACE) inhibitory activity and the concentration of the 2 ACE-inhibiting tripeptides Val-Pro-Pro (VPP) and Ile-Pro-Pro (IPP) were studied during cheese ripening in 7 Swiss cheese varieties. The semi-hard cheeses Tilsiter, Appenzeller 1/4 fat, Tête de Moine, and Vacherin fribourgeois and the extra-hard and hard cheeses Berner Hobelkäse, Le Gruyère, and Emmentaler were investigated. Three loaves of each variety manufactured in different cheese factories were purchased at the beginning of commercial ripeness and investigated at constant intervals until the end of the usual sale period. Good agreement was found between ACE-inhibitory activity and the total concentration of VPP and IPP at advanced ripening stages. In most of the investigated varieties ACE-inhibitory activity and the concentration of the 2 tripeptides initially increased during the study period. A decline in the concentration of VPP and IPP was obtained toward the end of the investigated period for Tilsiter and Gruyère. The ratio of VPP/IPP decreased during ripening in all varieties with the exception of Emmentaler. However, large variations were observed among the cheese varieties as well as the individual loaves of the same variety. Chemical characterization of the investigated cheeses revealed that qualitative differences in the proteolysis pattern, not quantitative differences in the degree of proteolysis, are responsible for the observed variations in the concentrations of VPP and IPP. The presence of Lactobacillus helveticus in the starter culture was associated with elevated concentrations of VPP and IPP. The results of the present study show that concentrations of VPP and IPP above $100 \mathrm{mg} / \mathrm{kg}$ are attainable in semi-hard cheese varieties after ripening periods of about 4 to $7 \mathrm{mo}$ and that stable concentrations of the 2 antihypertensive tripeptides can be expected over several weeks of cheese ripening.
\end{abstract}

Received July 7, 2008.

Accepted November 5, 2008.

${ }^{1}$ Corresponding author: daniel.wechsler@alp.admin.ch
Key words: angiotensin-converting enzyme-inhibiting peptide, cheese ripening, Val-Pro-Pro, Ile-Pro-Pro

\section{INTRODUCTION}

Cheese ripening is a complex process that involves a large number of biochemical reactions. Detailed studies on cheese ripening have been carried out for various Swiss cheese varieties such as Appenzeller (Steffen et al., 1993b), Tilsiter (Steffen et al., 1993a), Raclette (Schär et al., 1992), Emmentaler (Bachmann et al., 1999), Gruyère (Steffen et al., 1992), and Sbrinz (Sollberger et al., 1991). During secondary proteolysis a large number of peptides varying in chain length are released from caseins through the action of proteolytic enzymes from milk, raw milk flora, milk-clotting enzymes, and microbial proteases from lactic starter cultures and adjunct cultures. In a study of Emmentaler, 91 peptides were found (Bütikofer et al., 1998) and in another report more than 100 peptides were detected in the watersoluble extracts (Gagnaire et al., 2001). A total of 107 peptides were reported in different fractions of artisanal or industrial Manchego cheese (Gómez-Ruiz et al., 2007).

Milk protein is a rich source of biologically active peptides that may be released through the action of proteolytic enzymes during cheese ripening. Some of these peptides have been shown to inhibit angiotensinconverting enzyme (ACE) and are therefore associated with antihypertensive properties (Bachmann et al., 2003). The study by Okamoto et al. (1995) was one of the first to describe ACE inhibition in cheese. Large differences in ACE inhibition were shown in vitro in water-soluble extracts (Meisel et al., 1997; Smacchi and Gobbetti, 1998; Haileselassie et al., 1999; Saito et al., 2000; Stepaniak et al., 2001; Ong et al., 2007; Ong and Shah, 2008a, b) as well as in the ethanol-soluble fraction (Pripp et al., 2006) of various cheese varieties.

In recent years a large number of ACE-inhibiting peptides from various cheese varieties have been isolated and identified. For instance, 22 peptides could be identified in Manchego aged 8 mo (Gómez-Ruiz et al., 2002) and a total of 41 peptides were found in 6 
other Spanish cheeses (Gómez-Ruiz et al., 2006). In a new type of low-fat ripened cheese, 3 peptides with high ACE-inhibiting activity were found (Ryhänen et al., 2001) and in ovine and caprine cheese-like systems manufactured with proteases from Cynara cardunculus, 4 such peptides (Silva et al., 2006) were identified.

Among the various ACE-inhibiting peptides, the lactotripeptides Val-Pro-Pro (VPP) and Ile-Pro-Pro (IPP), first isolated from Lactobacillus helveticus-fermented milk (Nakamura et al., 1995a), have been the subject of various in vivo studies. The antihypertensive activity of these 2 peptides was demonstrated several times in spontaneously hypertensive rats (Nakamura et al., 1995b; Masuda et al., 1996; Sipola et al., 2001) as well as in patients with mild hypertension (Hata et al., 1996; Seppo et al., 2002, 2003; Tuomilehto et al., 2004; Jauhiainen et al., 2005). Two recent studies showed that the 2 tripeptides may be naturally present in several cheese varieties of Swiss origin at concentrations similar to those found in fermented milk products with bloodpressure-lowering properties (Bütikofer et al., 2007, 2008). In an initial study with 44 individual samples of various cheese varieties, the concentrations of VPP and IPP varied between $0 \mathrm{mg} / \mathrm{kg}$ in Mozzarella and $320 \mathrm{mg} / \mathrm{kg}$ in Berner Hobelkäse (Bütikofer et al., 2007). Although Bernard et al. (2005) previously reported a total concentration of $566.88 \mathrm{mg} / \mathrm{kg}$ of VPP and IPP in blue cheese, only moderate concentrations were found in the investigated soft cheeses probably because of poor proteolysis (Bütikofer et al., 2007). Therefore, in a second study, our investigations focused on semi-hard, hard, and extra-hard cheeses made from raw or thermized milk. In the group of semi-hard cheeses $(n=28)$, the total concentration of VPP and IPP was on average at $89 \mathrm{mg} / \mathrm{kg}$ (range: 7 to $317 \mathrm{mg} / \mathrm{kg}$ ) and in 73 samples of extra-hard and hard cheeses, a mean concentration of $96 \mathrm{mg} / \mathrm{kg}$ (range: 2 to $425 \mathrm{mg} / \mathrm{kg}$ ) of VPP and IPP was obtained (Bütikofer et al., 2008).

The results of several studies suggest that ACE-inhibitory activity and the concentration of the involved peptides increased with cheese ripening, but later declined when proteolysis exceeded a certain degree (Haque and Chand, 2008). For example, in 3 samples of Emmentaler manufactured in a factory using a traditional whey culture the total concentrations of VPP and IPP were $139.3,184.6$, and $165.6 \mathrm{mg} / \mathrm{kg}$ at 4,9 , and 12 mo of aging, respectively, indicating a maximum value in medium-aged cheese (Bütikofer et al., 2008). Meisel et al. (1997) measured the ACE inhibition of young, medium, and old Gouda cheeses and also obtained an optimum in medium-aged cheese. Saito et al. (2000) obtained a significantly greater reduction of blood pressure in spontaneously hypertensive rats with Gouda aged for 8 mo compared with Gouda aged for 24 mo. In Festivo, a newly developed functional cheese, ACE inhibition increased to over $50 \%$ at wk 13 and then decreased in cheese aged 20 wk (Ryhänen et al., 2001). However, the monitoring of 5 ACE-inhibiting peptides in 4 batches of Manchego during a 12-mo ripening period did not show an age-dependent trend (Gómez-Ruiz et al., 2004). In Cheddar cheeses produced with probiotic adjunct cultures increased ACE inhibition was obtained after 24 wk of ripening at 4 and $8^{\circ} \mathrm{C}$ compared with control cheese (Ong and Shah, 2008a). In Cheddar cheeses made with starter lactococci (control), Lactobacillus acidophilus L10 and starter lactococci, or Lactobacillus acidophilus L10, Lactobacillus helveticus H100, and starter lactococci, the percentage of ACE inhibition increased by increasing the temperatures from 4 to 8 to $12^{\circ} \mathrm{C}$, but the $\mathrm{ACE}$ inhibitory activity among these cheeses did not differ significantly (Ong and Shah, 2008b). In our previous studies wide variations were observed in the concentrations of VPP and IPP within samples of the same age from the same variety (Bütikofer et al., 2007, 2008) underlining the fact that other factors besides ripening may have a more pronounced effect on the concentrations of ACE-inhibiting peptides. The results of recent studies show that a better understanding of the factors affecting the concentrations of ACE-inhibitory peptides in cheese is still needed to develop functional cheeses with antihypertensive potential. The aim of the present study was therefore to monitor the ACE-inhibitory activity and concentrations of the 2 lactotripeptides, VPP and IPP, in individual loaves of Appenzeller 1/4 fat, Tilsiter, Tête de Moine, Vacherin fribourgeois, Emmentaler, Gruyère, and Berner Hobelkäse from the beginning of commercial ripeness until full ripeness and to investigate differences among the cheeses manufactured by several producers of the same variety.

\section{MATERIALS AND METHODS}

\section{Selection of Cheeses and Ripening Conditions}

Three loaves each of Appenzeller 1/4 fat, Tilsiter, Tête de Moine, Vacherin fribourgeois, Emmentaler, Gruyère, and Berner Hobelkäse manufactured in different cheese factories were purchased before the usual sale date and further ripened and cured under typical conditions in the ripening cellars of the research station Agroscope (Liebefeld, Switzerland) until the end of the usual sale period. The cheeses were manufactured according to the directions of the individual cheese associations as described previously (Bütikofer et al., 2008).

Two of the semi-hard cheeses, Appenzeller 1/4 fat and Tilsiter, were investigated from 3 to $10 \mathrm{mo}$ of aging, and the other two, Tête de Moine and Vacherin 
Table 1. Chemical characterization (means with SD in parentheses) of the investigated cheese varieties at the end of ripening ${ }^{1}$

\begin{tabular}{|c|c|c|c|c|c|c|c|c|c|}
\hline Cheese variety & Age, d & $\begin{array}{l}\text { Protein, } \\
\mathrm{g} / \mathrm{kg}\end{array}$ & $\begin{array}{c}\text { TCASN/ } \\
\text { TN } \times \\
100, \%\end{array}$ & $\begin{array}{l}\text { WSN, } \\
\mathrm{g} / \mathrm{kg}\end{array}$ & $\begin{array}{l}\mathrm{WSN} / \mathrm{TN} \\
\times 100, \%\end{array}$ & $\begin{array}{l}\text { Fat, } \\
\mathrm{g} / \mathrm{kg}\end{array}$ & $\begin{array}{l}\text { FDM, } \\
\mathrm{g} / \mathrm{kg}\end{array}$ & $\begin{array}{l}\mathrm{MFFB}, \\
\mathrm{g} / \mathrm{kg}\end{array}$ & $\begin{array}{l}\text { Moisture, } \\
\mathrm{g} / \mathrm{kg}\end{array}$ \\
\hline Berner Hobelkäse $(\mathrm{n}=3)$ & 730 & $\begin{array}{r}288.3 \\
(6.6)\end{array}$ & $\begin{array}{l}26.1 \\
(4.1)\end{array}$ & $\begin{array}{l}14.5 \\
(0.7)\end{array}$ & $\begin{array}{l}32.1 \\
(2.3)\end{array}$ & $\begin{array}{l}398.2 \\
(10.6)\end{array}$ & $\begin{array}{l}528.7 \\
(11.1)\end{array}$ & $\begin{array}{r}410.0 \\
(1.7)\end{array}$ & $\begin{array}{r}246.3 \\
(4.2)\end{array}$ \\
\hline Emmentaler $(\mathrm{n}=3)$ & 516 & $\begin{array}{c}290.1 \\
(2.5)\end{array}$ & $\begin{array}{l}25.4 \\
(0.6)\end{array}$ & $\begin{array}{l}14.1 \\
(0.4)\end{array}$ & $\begin{array}{l}30.9 \\
(1.0)\end{array}$ & $\begin{array}{r}344.0 \\
(9.5)\end{array}$ & $\begin{array}{r}509.3 \\
(8.5)\end{array}$ & $\begin{array}{r}494.9 \\
(5.9)\end{array}$ & $\begin{array}{r}324.5 \\
(7.9)\end{array}$ \\
\hline Le Gruyère ( $\mathrm{n}=3$ ) & 516 & $\begin{array}{r}259.7 \\
(8.2)\end{array}$ & $\begin{array}{l}29.2 \\
(1.5)\end{array}$ & $\begin{array}{l}12.8 \\
(1.2)\end{array}$ & $\begin{array}{l}31.3 \\
(1.9)\end{array}$ & $\begin{array}{r}336.0 \\
(7.0)\end{array}$ & $\begin{array}{r}512.4 \\
(7.6)\end{array}$ & $\begin{array}{r}518.6 \\
(5.0)\end{array}$ & $\begin{array}{r}344.2 \\
(5.8)\end{array}$ \\
\hline Tilsiter $(\mathrm{n}=3)$ & 300 & $\begin{array}{r}272.8 \\
(8.3)\end{array}$ & $\begin{array}{l}31.6 \\
(0.4)\end{array}$ & $\begin{array}{l}18.2 \\
(0.8)\end{array}$ & $\begin{array}{l}42.6 \\
(1.7)\end{array}$ & $\begin{array}{r}308.5 \\
(2.2)\end{array}$ & $\begin{array}{r}498.2 \\
(9.5)\end{array}$ & $\begin{array}{r}550.2 \\
(2.4)\end{array}$ & $\begin{array}{r}380.2 \\
(7.7)\end{array}$ \\
\hline Tête de Moine $(\mathrm{n}=3)$ & 210 & $\begin{array}{r}253.0 \\
(5.3)\end{array}$ & $\begin{array}{l}16.5 \\
(2.4)\end{array}$ & $\begin{array}{l}12.4 \\
(0.7)\end{array}$ & $\begin{array}{l}31.1 \\
(1.1)\end{array}$ & $\begin{array}{r}355.5 \\
(5.5)\end{array}$ & $\begin{array}{r}533.8 \\
(6.6)\end{array}$ & $\begin{array}{r}517.9 \\
(3.4)\end{array}$ & $\begin{array}{c}333.3 \\
(3.4)\end{array}$ \\
\hline Vacherin fribourgeois $(\mathrm{n}=3)$ & 210 & $\begin{array}{r}245.5) \\
(4.8)\end{array}$ & $\begin{array}{l}23.6 \\
(1.1)\end{array}$ & $\begin{array}{l}12.9 \\
(0.6)\end{array}$ & $\begin{array}{l}33.7 \\
(1.7)\end{array}$ & $\begin{array}{l}301.8 \\
(10.3)\end{array}$ & $\begin{array}{l}513.8 \\
(14.3)\end{array}$ & $\begin{array}{r}590.8 \\
(4.2)\end{array}$ & $\begin{array}{c}412.0 \\
(4.3)\end{array}$ \\
\hline
\end{tabular}

${ }^{1} \mathrm{TN}=$ total nitrogen; TCASN $=120 \mathrm{~g} / \mathrm{L}$ TCA-soluble nitrogen; WSN = water-soluble nitrogen; FDM = fat in dry matter; MFFB = moisture on a fat-free basis.

fribourgeois, were investigated from 2 to 7 mo; the hard cheeses Emmentaler and Gruyère were investigated from 3 to 17 mo; and Hobelkäse, an extra-hard cheese from the Bernese Oberland, was investigated from 10 to 24 mo. Sampling was performed at different intervals depending on the variety as shown in Figures 1 and 2. At sampling, a vertical cylinder of $2 \mathrm{~cm}$ diameter was removed from the loaf at a distance of half of the radius of the cheese. After removal the samples were immediately frozen at $-20^{\circ} \mathrm{C}$ until further analysis.

At the end of ripening all cheeses were further analyzed for moisture, protein, TCA-soluble N (TCASN), and fat using standard methods as described previously (Bütikofer et al., 2007). A sensorial evaluation was also performed to exclude cheeses with sensory defects. Furthermore, fat in the dry matter and moisture on a fat-free basis were calculated. The results of the basic characterization of the investigated cheeses are summarized in Table 1.

\section{Materials}

Acetonitrile (HPLC grade) and formic acid (analytical grade) were purchased from Sigma-Aldrich Chemie GmbH (Buchs, Switzerland). Deionized water was prepared on a Milli-Q installation from Millipore (Volketswil, Switzerland). Standard peptides Val-ProPro, Ile-Pro-Pro, and Pro-Pro-Pro-Pro (PPPP) were purchased from Bachem (Bubendorf, Switzerland); ACE from Sigma-Aldrich Chemie GmbH; hippuryl-HisLeu-OH from Bachem; ethyl acetate, boric acid, $\mathrm{NaCl}$ and $\mathrm{HCl} 1 M$ from Merck AG (Dietikon, Switzerland); and Microcon ym-3 from Millipore AG. Borate buffer $0.1 M$ (pH 8.3) containing $\mathrm{NaCl} 0.3 M$, hippuryl-His-
Leu $(5 \mathrm{mM})$ in borate buffer, and $\mathrm{ACE}(0.5 \mathrm{U} / \mathrm{mL})$ in borate buffer were prepared fresh daily.

\section{Sample Preparation}

After removing the rind, the samples were grated and $5 \mathrm{~g}$ of cheese was homogenized in $10 \mathrm{~mL}$ of distilled water for $15 \mathrm{~s}$ at 17,000 rpm using a Polytron homogenizer from Kinematica AG (Littau, Switzerland) and shaken in a water bath for $60 \mathrm{~min}$ at $40^{\circ} \mathrm{C}$. The samples were centrifuged for $30 \mathrm{~min}$ at $4^{\circ} \mathrm{C}$ and $10,000 \times \mathrm{g}$. The aqueous solution was removed from below the fat layer with a syringe and $500 \mu \mathrm{L}$ was filtered through a Microcon ym-3 filter by centrifugation at $14,000 \times g$ and room temperature for $99 \mathrm{~min}$. Filtrates were stored at $-20^{\circ} \mathrm{C}$.

\section{Determination of ACE Inhibition}

A diluted filtrate $(1: 10)$ of the water-soluble extract was used for the determination of ACE inhibition, which was performed according to the method of Cushman and Cheung (1970) as modified by Parrot et al. (2003). Samples of $20 \mu \mathrm{L}$ were added to $50 \mu \mathrm{L}$ of substrate (hippuryl-His-Leu-OH, $5 \mathrm{mM}$ ) in 1.5-mL Eppendorf tubes, mixed well, and rapidly centrifuged. The reaction was started by the addition of $5 \mu \mathrm{L}$ of ACE $(0.5$ $\mathrm{U} / \mathrm{mL}$ ), and the mixture was incubated for $1 \mathrm{~h}$ at $37^{\circ} \mathrm{C}$. The $100 \%$ activity value was determined by incubating $20 \mu \mathrm{L}$ of $\mathrm{H}_{2} \mathrm{O}$ in place of a sample. Blanks were measured by replacing ACE with water. The reaction was stopped by the addition of $62.5 \mu \mathrm{L}$ of $1 \mathrm{M} \mathrm{HCl}$. Then, $375 \mu \mathrm{L}$ of ethyl acetate was added and the solution was well mixed and centrifuged. The supernatant was 
dried in a heating block at $120^{\circ} \mathrm{C}$ and an equal volume of water was added. Measurements were carried out at $228 \mathrm{~nm}$ in a Nanodrop spectrophotometer (Witec, Littau, Switzerland). Inhibition of ACE was expressed as a percentage of the reduction of $100 \%$ activity obtained with water in place of a sample in the assay.

\section{Determination of ACE-Inhibiting Peptides VPP and IPP}

The concentrations of the ACE-inhibiting tripeptides VPP and IPP were determined in the filtrate of the water-soluble extract of cheese in a single analysis. The HPLC separation was performed on a PLRP-S column $1 \times 150 \mathrm{~mm}(300 \AA, 3 \mu \mathrm{m})$ from Polymer Laboratories (Ercatech, Bern, Switzerland) with a Rheos 2200 pump (Flux Instruments, Basel, Switzerland). The temperature of the column was maintained at $25^{\circ} \mathrm{C}$ in a LC-Pelcooler column oven (Labsource, Reinach, Switzerland). The sample vials were kept at $8^{\circ} \mathrm{C}$ and an auto-sampler (CTC Analytics, Zwingen, Switzerland) was used for automatic injection. Ten microliters of sample solution and $10 \mu \mathrm{L}$ of an internal standard solution were injected together. Experiments using HPLC coupled with triple MS detection (HPLC-MS ${ }^{3}$ ) were performed on a Finnigan LTQ linear ion trap mass spectrometer (Spectronex, Basel, Switzerland). The complete system was controlled by Xcalibur Software Version 1.4 (Thermo Electron Corp., Waltham, MA). The following solvent system was used for the analysis: solvent $\mathrm{A}=0.5 \%(\mathrm{vol} / \mathrm{vol})$ formic acid in water and solvent $\mathrm{B}=0.5 \%$ ( $\mathrm{vol} / \mathrm{vol}$ ) formic acid in acetonitrile. The flow was set to $70 \mu \mathrm{L} / \mathrm{min}$ for the whole analysis. The separation of the peptides was performed with a linear gradient of 0 to $40 \%$ solvent B within 30 min.

The first $4 \mathrm{~min}$ of the eluant was directed to waste to reduce salt deposit on the transfer capillary of the MS instrument. The $\mathrm{MS}^{3}$ spectra were recorded from 4 to $15 \mathrm{~min}$. Separate MS experiments were set up for VPP, IPP, and the internal standard PPPP. The retention time of VPP, IPP, and PPPP was 8, 11.5, and 12 min, respectively. For the HPLC-MS ${ }^{3}$ experiments the same parameters were used as described previously (Bütikofer et al., 2007).

\section{RESULTS}

\section{Characterization of the Investigated Cheeses}

The basic characterization of the investigated cheese loaves was performed at the end of the ripening period. The results were in the range of the expected limits for the investigated varieties (Table 1). As a result of the high water content and the long ripening period (10 mo), 2 of the semi-hard cheeses (Appenzeller 1/4 fat and Tilsiter) had the highest ratio of water-soluble $\mathrm{N}$ (WSN)/total N (TN) (>42\%). In the 2 other semihard cheeses (Tête de Moine and Vacherin fribourgeois) that were ripened for only $7 \mathrm{mo}$, considerably lower ratios in the range of 31.1 to $33.7 \%$ were obtained. In the 2 hard cheeses (Emmentaler and Gruyère) and the extra-hard cheese (Berner Hobelkäse) similar mean values were obtained for $\mathrm{WSN} / \mathrm{TN}$ in the range of 30.9 to $32.1 \%$. The lowest mean values for the TCASN/TN ratio were obtained for the varieties Tête de Moine and Vacherin fribourgeois (16.5 and $23.6 \%$, respectively), whereas mean values in the range of 25.4 to $31.6 \%$ were obtained for the other varieties. Both the chemical parameters of proteolysis (TCASN/TN and WSN/ $\mathrm{TN}$ ) and a sensorial evaluation at the end of the study period confirmed the high degree of ripeness of all the investigated cheeses.

\section{Changes in ACE Inhibition and Concentrations of VPP and IPP During Ripening of Semi-Hard Cheeses}

Inhibition of ACE and the concentrations of VPP and IPP were monitored from the beginning of commercial ripeness to the end of the usual consumption period of the investigated varieties. Because of the rapid ripening of Tête de Moine and Vacherin fribourgeois, the loaves of these 2 varieties were sampled at monthly intervals between the ages of 2 and 7 mo, whereas the loaves of the other 2 semi-hard varieties were investigated between the ages of 3 and 10 mo. The individual levels of ACE inhibition, VPP + IPP contents, and the VPP/ IPP ratios are shown in Figure 1. The individual figures show a relative continuous progression of the 3 parameters in the investigated loaves during ripening.

For all 3 loaves of Tilsiter the curves of ACE inhibition and the total concentration of VPP + IPP showed the same evolution over ripening time. The values of the ACE inhibition initially ranged between 43 and $48 \%$, then increased continuously in all cheeses to a plateau close to $70 \%$, and finally decreased to $60 \%$ during the last month of ripening. Similarly, the concentrations of VPP + IPP increased simultaneously from initial values below $60 \mathrm{mg} / \mathrm{kg}$ to a plateau in the range of approximately 130 to $160 \mathrm{mg} / \mathrm{kg}$ at the age of 7 to 8 mo and tended to decrease slowly in the final ripening period. The ratio of VPP/IPP increased in all 3 loaves of Tilsiter during the initial part of the investigated period to maximal values of $7.3,8.8$, and 10.2 and then decreased continuously to minimal values of $3.7,4.6$, and 4.9, respectively, at the end of ripening.

In contrast to Tilsiter, larger differences were obtained among the individual loaves of Appenzeller 1/4 fat, Tête de Moine, and Vacherin fribourgeois. Among 
the 3 loaves of each of these varieties, similar behavior was only observed in 2 loaves, whereas the third loaf exhibited a distinctly different manner.

In 2 loaves of Appenzeller 1/4 fat, ACE inhibition initially ranged between 46 and $56 \%$ and attained a plateau close to $75 \%$ at the end of ripening. In contrast, the highest level of ACE inhibition measured in the third loaf was $65 \%$ and was attained at the start of commercial ripeness. In this cheese, ACE inhibition re- mained constant over several months before it sharply decreased to $40 \%$ during the final month of ripening. The individual values for the sum of VPP + IPP exhibited similar trends. In the 2 loaves that exhibited an increase in ACE inhibition during ripening, the sum of VPP + IPP ranged between 8.2 and $235.2 \mathrm{mg} / \mathrm{kg}$, showing a simultaneous and continuous increase over the whole investigation period. Contrarily, in the third cheese, the sum of VPP + IPP increased slowly from

\section{Appenzeller $1 / 4$ fat}
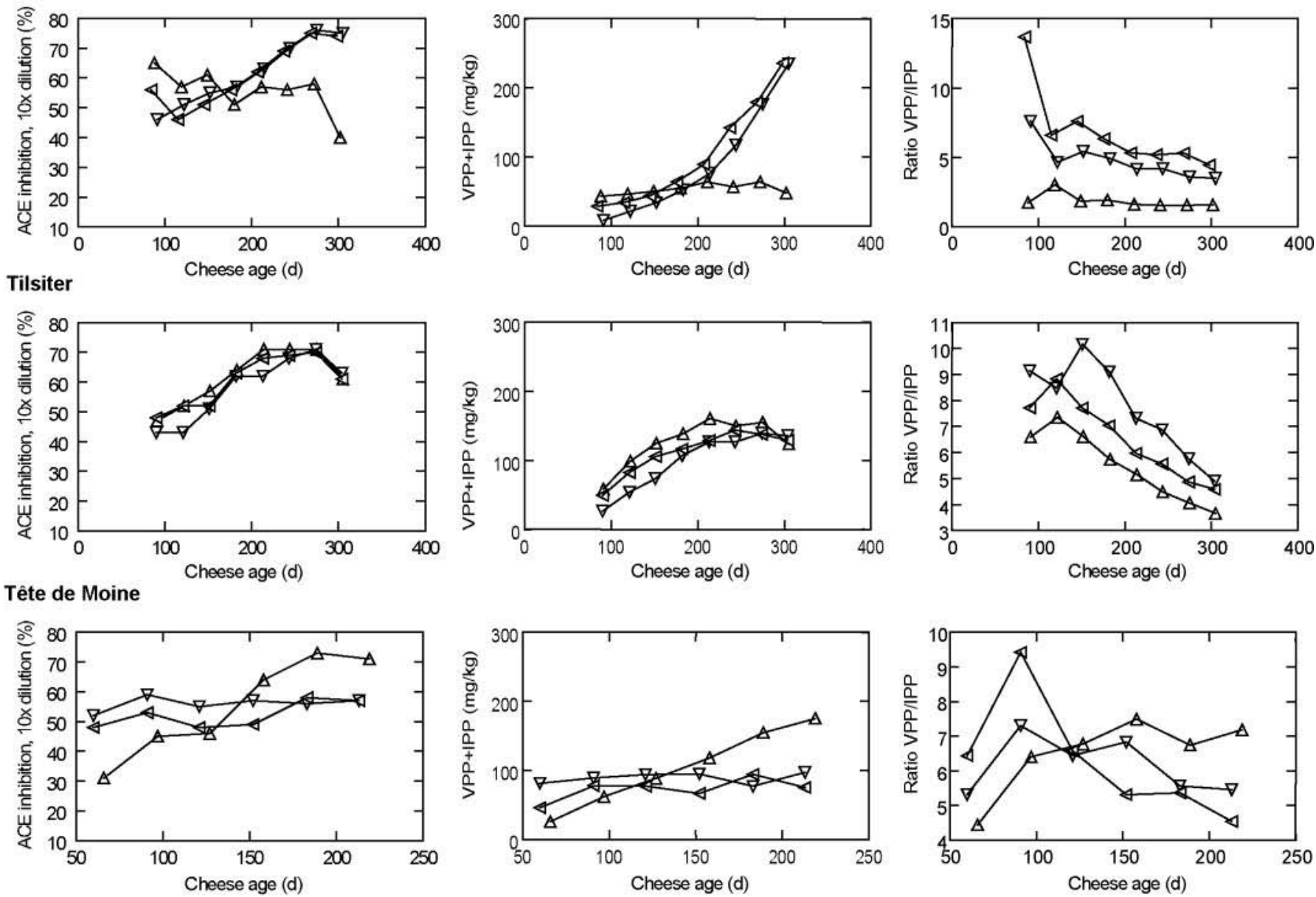

Vacherin fribourgeois
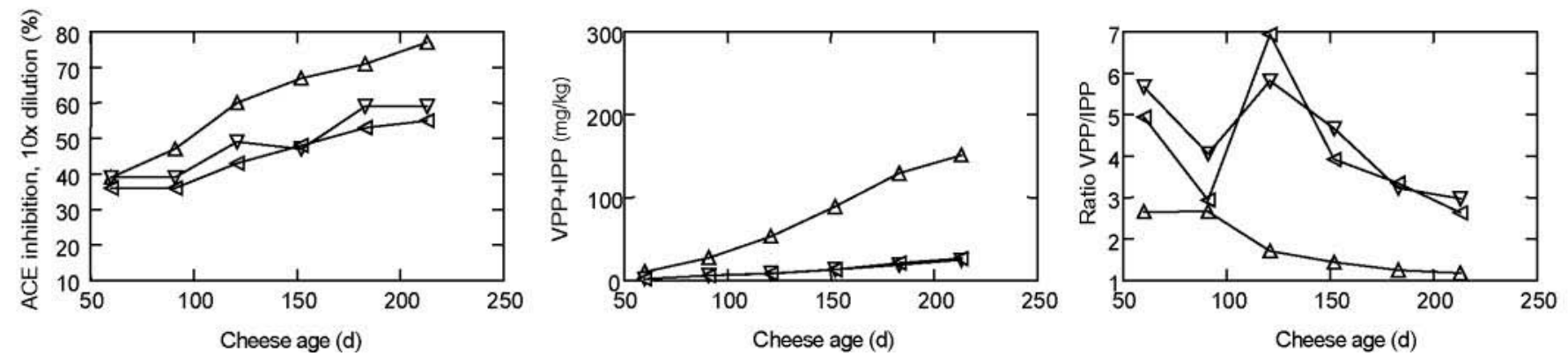

Figure 1. Changes in angiotensin-converting enzyme (ACE) inhibition and concentrations and ratio of the antihypertensive tripeptides ValPro-Pro (VPP) and Ile-Pro-Pro (IPP) during ripening of Swiss semi-hard cheese varieties. 
43.0 to $63.8 \mathrm{mg} / \mathrm{kg}$ during the first months of ripening and then decreased to $47.5 \mathrm{mg} / \mathrm{kg}$ during the final month. The ratio of VPP/IPP in the third loaf exhibited an almost constant ratio close to $2: 1$, whereas in the other 2 loaves, the ratio ranged between 13.7 and 3.5 and showed a marked decrease during ripening.

In the Tête de Moine group, 2 of the 3 investigated cheeses showed a constant condition over the whole investigated period for $\mathrm{ACE}$ inhibition as well as for the concentration of VPP + IPP. The values of ACE inhibition remained at a constant level between 48 and $59 \%$ and variations in the concentration of VPP + IPP were limited (values mostly between 75 and $95 \mathrm{mg} / \mathrm{kg}$ ). However, the third cheese exhibited different behavior. In cheese aged for 2 mo, ACE inhibition was $31 \%$ (the lowest level of the 3 investigated loaves); after 6 mo, ACE inhibition was at $73 \%$ (the highest level of the 3 loaves). Similarly, the concentration of VPP + IPP in the third cheese started at a low level of $25.7 \mathrm{mg} / \mathrm{kg}$, but increased to $174.9 \mathrm{mg} / \mathrm{kg}$ at the end of ripeningthe highest value of the 3 cheeses. In this cheese, the ratio of VPP/IPP tended to increase over the ripening period, whereas in the other 2 cheeses the ratio decreased after the age of 3 mo.

In the Vacherin fribourgeois group, the 3 cheeses showed very similar properties at the beginning of the investigation period. However, with ongoing ripening, the behavior of one cheese differed more and more. In contrast to this loaf, which exhibited an ACE inhibition of $77 \%$ at the end of ripening, ACE inhibition in the other 2 loaves reached maximum values of only of 59 and $55 \%$. Similarly, the concentration of VPP + IPP barely increased in these 2 cheeses and at the end of ripening reached a low value close to $25 \mathrm{mg} / \mathrm{kg}$, whereas the cheese with the strongest increase in ACE inhibition attained a maximal concentration of $151.1 \mathrm{mg} / \mathrm{kg}$ after 7 mo. Surprisingly, the cheese with the greatest concentration of VPP + IPP showed the lowest ratio of VPP/IPP over the whole period.

\section{Changes in ACE Inhibition and Concentrations of VPP and IPP During Ripening of Hard and Extra-Hard Cheeses}

Commercial ripeness of the 2 hard cheeses (Emmentaler and Gruyère) begins after minimal ripening periods of 4 and 5 mo, respectively. However, both varieties are often ripened for considerably longer periods (up to $1.5 \mathrm{yr}$ ). The extra-hard variety Berner Hobelkäse is an alpine cheese, which is first smear-ripened for 6 mo, and then washed and dry-ripened for another $12 \mathrm{mo}$. At consumption, which usually takes place between 18 and $36 \mathrm{mo}$, the cheese is planed to obtain thin slices. In our study we monitored the behavior of ACE inhibition,
$\mathrm{VPP}+\mathrm{IPP}$ concentrations, and the VPP/IPP ratio in 3 loaves of each variety during the usual period of consumption (Figure 2). Only small differences were observed for the investigated parameters among the 3 loaves each of Emmentaler and Gruyère. However, the behavior of the investigated parameters differed considerably among the 3 varieties.

After an initial decrease, ACE inhibition continuously increased in all Emmentaler cheeses and reached a plateau after ripening for $7 \mathrm{mo}$, with a value close to $50 \%$ that remained stable until the end of the study period. Although the concentration of VPP + IPP increased continuously during ripening, the maximal concentration of VPP + IPP remained modest in all loaves $(<55$ $\mathrm{mg} / \mathrm{kg}$ ). Remarkably, the ratio of VPP/IPP tended to increase during ripening and was close to 10:1 at the end of the period-distinctly higher than in all other investigated varieties.

In Gruyère cheese, the greatest level of $\mathrm{ACE}$ inhibition was between 45 and $50 \%$ and was observed in samples aged less than 10 mo. In very mature cheese, ACE inhibition decreased markedly to values below $30 \%$. Similarly, the concentration of VPP + IPP was greatest at the start of commercial ripeness (maxima in the range of 61.0 to $70.9 \mathrm{mg} / \mathrm{kg}$ ) and continuously decreased until the end of ripening (minima in the range of 4.9 to $18.6 \mathrm{mg} / \mathrm{kg}$ ). The ratio of VPP/IPP initially increased in all 3 loaves (maxima in the range of 6.1 to 11.1) and declined with prolonged ripening in all loaves to a value close to $2: 1$.

In the 3 loaves of Berner Hobelkäse, the variations between the beginning and the end of ripening were low for ACE inhibition and the concentration of VPP + IPP. However, the values of the 3 cheeses differed. The cheese with the highest ACE inhibition $(\sim 48 \%)$ contained, on average, $55.7 \mathrm{mg} / \mathrm{kg}$ VPP + IPP, whereas the cheese with the lowest inhibition $(\sim 17 \%)$ contained on average only $6.5 \mathrm{mg} / \mathrm{kg}$ of the 2 tripeptides. The ratio of VPP/IPP was initially between 2.3 and 6.3 but tended to decrease during ripening in all loaves to values between 1.3 and 3.5 .

\section{DISCUSSION}

The aim of the present study was to investigate changes in ACE inhibition and the concentrations of the 2 tripeptides VPP and IPP during the ripening of different semi-hard (Appenzeller 1/4 fat, Tilsiter, Tête de Moine, and Vacherin fribourgeois), hard (Emmentaler and Gruyère), and extra-hard (Berner Hobelkäse) cheeses. In our previous studies, remarkably high concentrations of the 2 antihypertensive tripeptides were found in some commercial samples of the investigated varieties (Bütikofer et al., 2007, 2008). Milk pretreat- 

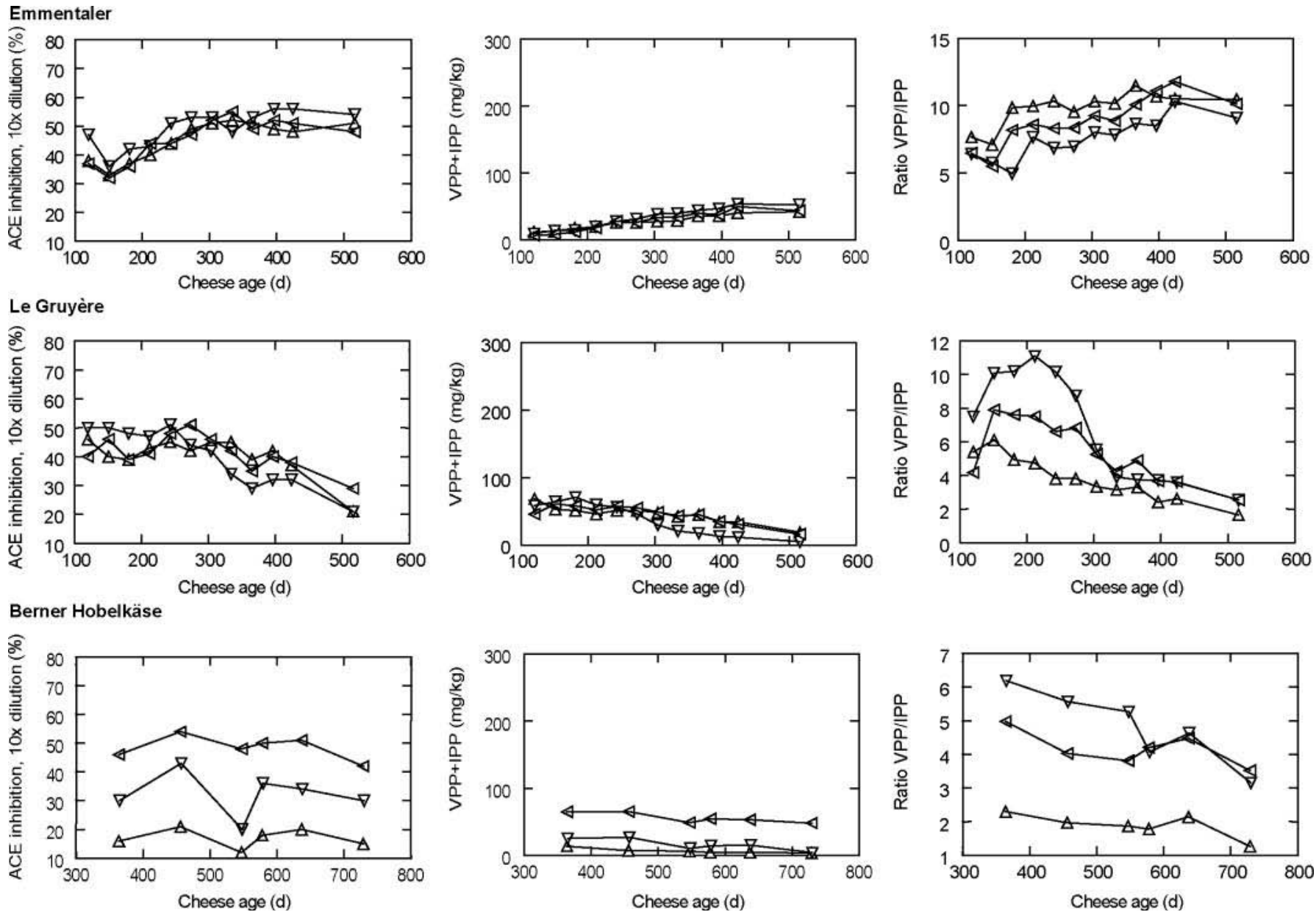

Figure 2. Changes in angiotensin-converting enzyme (ACE) inhibition and concentrations and ratio of the antihypertensive tripeptides ValPro-Pro (VPP) and Ile-Pro-Pro (IPP) during ripening of Swiss hard and extra-hard cheese varieties.

ment, cultures, scalding conditions, and ripening times were identified as important key factors that determine the concentrations of VPP and IPP. However, unexpectedly large variations were found between samples from the same variety. It remained unclear whether these variations resulted from differences in cheese making or ripening. For this reason, in the present study, we recorded the ACE-inhibitory activity and the concentrations of VPP and IPP in individual loaves from different manufacturers during the period of commercial ripeness. It was expected that the results of the present study would improve the knowledge base for the development of a functional cheese with antihypertensive potential, showing the highest levels of VPP and IPP at the optimal degree of ripening.

\section{Impact of Proteolysis and Ripening on ACE Inhibition and Concentrations of VPP and IPP}

During cheese ripening, various proteases and peptidases are involved in the breakdown of caseins into smaller peptides and amino acids. Proteolysis is important for the development of a characteristic cheese flavor and texture and has been studied in detail in Appenzeller (Steffen et al., 1993b), Tilsiter (Steffen et al., 1993a), Emmentaler (Bachmann et al., 1999), Gruyère (Steffen et al., 1992), and Berner Hobelkäse (Jakob et al., 2007) cheeses. During ripening, the ongoing proteolysis results in a continuous increase of the ratios WSN/TN and TCASN/TN, which are reliable indicators for the breakdown of casein. At the end of ripening, the total concentration of VPP and IPP differed greatly in the individual loaves of Appenzeller 1/4 fat, Vacherin fribourgeois, and Tête de Moine. However, very similar ratios for WSN/TN and TCASN/TN were obtained in all 3 loaves of the same variety (individual data not shown). These results suggest that qualitative differences in the proteolysis pattern, not quantitative differences in the degree of proteolysis, are responsible for the observed variations in the concentrations of VPP and IPP. The release of VPP and IPP seems to require a specific breakdown of caseins and for that 
reason, the concentration of the 2 tripeptides can differ considerably even among cheeses of the same variety produced by different manufacturers.

General proteolysis leads to the release of a large number of water-soluble peptides with ACE-inhibiting properties. As shown in Figures 1 and 2, the 10-folddiluted water-soluble extracts of all investigated cheeses showed, in the in vitro assay, considerable ACE inhibition in the range of 31 to $65 \%$ at the beginning of commercial ripeness. With the exception of 1 loaf of Appenzeller 1/4 fat, ACE inhibition tended to increase in all semi-hard cheeses and Emmentaler during ripening. However, the 3 loaves of Tilsiter cheese showed a small decrease in ACE inhibition at the end of commercial ripeness. Similarly, a remarkable decline in ACE inhibition was observed in Gruyère cheeses over the whole study period. The results obtained confirm that the concentration of ACE-inhibiting peptides generally increases during the initial period of cheese ripening, but starts to decline when proteolysis exceeds a certain level. Similarly, Meisel et al. (1997) found ACE inhibition of $70 \%$ in medium-aged Gouda cheese, whereas lower values were obtained in younger and older Gouda cheeses (51.8 and $34.6 \%$, respectively). However, Saito et al. (2000) reported ACE inhibitions of $78.2 \%$ for Gouda aged 8 mo and $75.5 \%$ for Gouda aged 24 mo. The results from the present study and the literature indicate that the behavior of ACE inhibition is not only related to ripening but also to individual manufacturing conditions. For this reason, it is difficult to specify an optimal ripening period for a cheese variety to yield cheeses with maximal ACE inhibition.

\section{Impact of Manufacture on ACE Inhibition and Concentrations of VPP and IPP During Ripening}

In our study we investigated 4 typical Swiss semihard cheese varieties with well-defined manufacturing procedures. Because of the existing directions of the individual cheese associations, the manufacturers of the same variety are forced to use uniform processing conditions. It is unlikely, therefore, that differences in milk pretreatment, scalding, and ripening conditions account for the large variation in the concentration of $\mathrm{VPP}+\mathrm{IPP}$ obtained among the individual loaves of Appenzeller 1/4 fat, Vacherin fribourgeois, and Tête de Moine. It is interesting to note that the 2 loaves of Appenzell $1 / 4$ fat cheese that exhibited a large increase in the concentration of VPP + IPP during ripening were made with a very similar combination of cultures (according to the product descriptions of cultures, one of the commercial cultures contained traces of Lactobacillus helveticus), whereas the third loaf, which displayed low concentrations of VPP + IPP, was made with a different combination of commercial cultures. Apart from the cultures, the 3 manufacturers used similar processing conditions (milk pretreatment at $64-68^{\circ} \mathrm{C}$, scalding at $31-36^{\circ} \mathrm{C}$ ). Interestingly, the same culture containing traces of Lactobacillus helveticus was also used, in combination with other cultures, by the 3 manufacturers of Tilsiter. This could explain the high concentrations of VPP + IPP and uniform behavior of ACE inhibition in the 3 loaves of that variety. However, compared with the 2 loaves of Appenzell 1/4 fat mentioned above, the evolution of VPP + IPP and ACE inhibition were distinct in the 3 loaves of Tilsiter, exhibiting a decrease in the final stage of commercial ripeness for both parameters. The results obtained for Vacherin fribourgeois also strongly suggest that the cultures used for cheese making have a dominant effect on ACE-inhibiting properties. The Vacherin fribourgeois cheese association has restricted the number of approved cultures. According to the product descriptions of these cultures, 3 of the approved commercial cultures contain Lactobacillus helveticus in combination with other strains such as Lactococcus cremoris, Lactococcus lactis, Lactococcus lactis ssp. diacetylactis, and Streptococcus salivarius ssp. thermophilus. The differences observed in the ACE-inhibiting properties among the 3 loaves of Vacherin fribourgeois seem to be related to the presence or absence of Lactobacillus helveticus in the starter culture. However, for the 3 loaves of the Tête de Moine variety, the situation was different. The 2 manufacturers of Tête de Moine with the highest and lowest concentrations of VPP + IPP used almost the same combination of cultures (which did not contain Lactobacillus helveticus). According to the list of requirements of this Protected Denomination of Origin cheese, only raw milk is allowed for manufacture and a scalding temperature between 46 and $53^{\circ} \mathrm{C}$ is applied. Thus, the results obtained suggest that lactic acid bacteria other than Lactobacillus helveticus or nonstarter lactic acid bacteria may contribute in an important way to the release of VPP and IPP during ripening. In commercial samples of Emmentaler, Gruyère, and Berner Hobelkäse, maximal values of 189.5, 129.0 and 353.0 $\mathrm{mg} / \mathrm{kg}$ and minimal values of $31.3,21.6$, and $6.8 \mathrm{mg} /$ $\mathrm{kg}$, respectively, were obtained in our previous study (Bütikofer et al., 2008). As a possible explanation for the large variations, we hypothesized that the presence or absence of Lactobacillus helveticus or other lactic acid bacteria may cause an "all-or-nothing" effect leading to 2 groups of cheeses containing either high or low concentrations of VPP and IPP. In the present study, the maximal concentrations of VPP + IPP obtained in samples of the investigated loaves were modest (Emmentaler $53.8 \mathrm{mg} / \mathrm{kg}$, Gruyère $70.9 \mathrm{mg} / \mathrm{kg}$, and Berner Hobelkäse $65.2 \mathrm{mg} / \mathrm{kg}$ ). Nevertheless, it is interesting 
to note that only minor differences between samples were observed in the concentrations of VPP + IPP in all the investigated loaves. It is unlikely, therefore, that abrupt changes occur in individual loaves during ripening. In contrast to this, the individual amounts of the 5 ACE-inhibiting peptides VRYL, DKIHPF, LPQNILP, VPSERYL, and KKYNVPQL varied greatly during ripening (at $15 \mathrm{~d}$, and 2, 4, 8, and $12 \mathrm{mo}$ ) in 4 batches of Manchego cheese (Gómez-Ruiz et al., 2004). These results indicate that the resistance of antihypertensive peptides to further degradation seems to be essential to obtain cheeses with stable ACE-inhibiting properties.

\section{Relationship Between ACE Inhibition and VPP and IPP Concentrations}

The individual values for the 21 cheeses of the 7 investigated varieties showed obvious parallels between ACE inhibition and the concentration of VPP and IPP (Figures 1 and 2). The individual results obtained for ACE inhibition and concentration of VPP + IPP in all investigated samples are summarized in Figure 3. Inhibition of ACE greater than $70 \%$ was only observed in 14 samples of semi-hard cheeses aged between 6 and 12 mo that contained more than $116 \mathrm{mg} / \mathrm{kg}$ of VPP + IPP. In contrast to this, the other 9 samples of Berner Hobelkäse and Gruyère aged between 12 and 24 mo all contained less than $19 \mathrm{mg} / \mathrm{kg} \mathrm{VPP} \mathrm{+} \mathrm{IPP} \mathrm{and} \mathrm{exhibited}$ ACE inhibition below 25\%. Thus, in samples with either very high or very low $\mathrm{ACE}$ inhibition there was good agreement between the concentration of VPP + IPP and ACE inhibition. However, there were 26 samples in total (aged between 5 and $10 \mathrm{mo}$ ) with concentrations of VPP and IPP $>116 \mathrm{mg} / \mathrm{kg}$ that had ACE inhibition between 57 and $77 \%$. A total of 37 samples (from cheeses aged for 2 to $24 \mathrm{mo}$ ) had $<19 \mathrm{mg} / \mathrm{kg}$ VPP + IPP and ACE inhibition ranging between 12 and $59 \%$. These 37 samples, mainly samples of Vacherin fribourgeois and Emmentaler, exhibited (despite the absence of high concentrations of VPP and IPP) a remarkable level of ACE inhibition above the $40 \%$ in the in vitro assay. High levels of ACE inhibition may already occur in the early stages of ripening because of the release of ACE-inhibiting peptides other than VPP and IPP. In contrast, the greatest concentrations of VPP and IPP were obtained in mature loaves of Appenzeller 1/4 fat, Tilsiter, and Tête de Moine (Figure 1). Peptides containing the terminal sequence Xaa-Pro-Pro are known to be resistant to further degradation by aminopeptidases and X-prolyl dipeptidyl aminopeptidases (Christensen et al., 1999). The resistance of VPP and IPP to gastrointestinal digestion also seems to be an important prerequisite for their antihypertensive effect in vivo (Ohsawa et al., 2008). Although our results for Gruyère

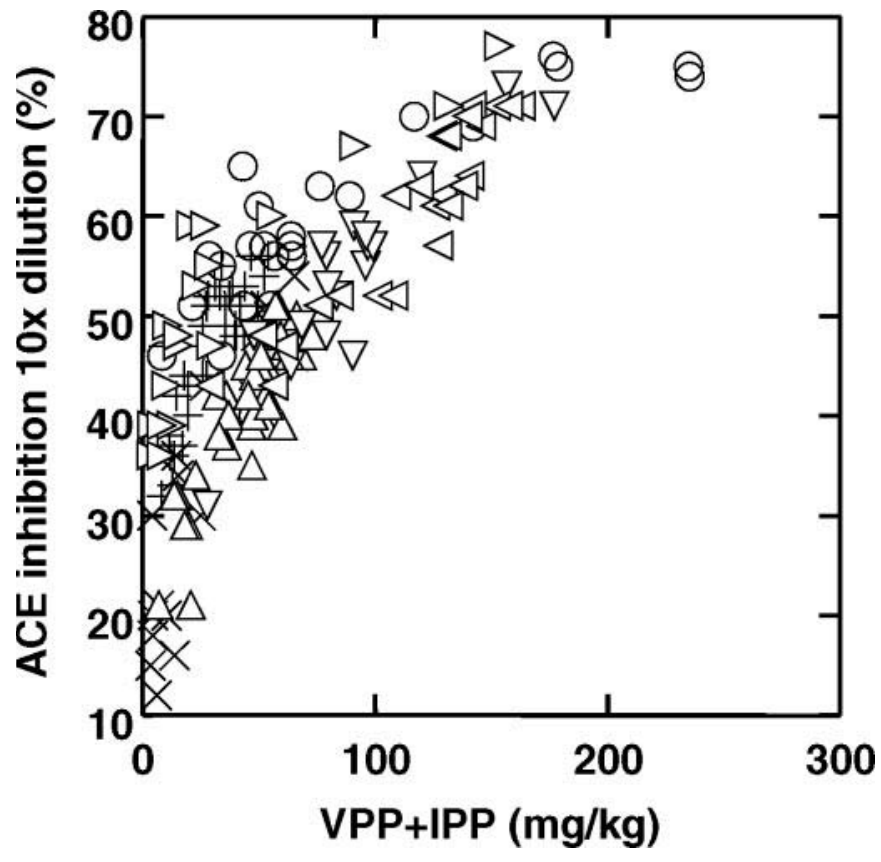

Figure 3. Concentration of Val-Pro-Pro (VPP) and Ile-Pro-Pro (IPP) and angiotensin-converting enzyme (ACE) inhibition obtained during ripening in individual samples of Appenzeller $1 / 4$ fat $(\bigcirc)$, Tête de Moine $(\nabla)$, Tilsiter $(\triangleleft)$, Vacherin fribourgeois $(\triangleright)$, Berner Hobelkäse $(\times)$, Emmentaler $(+)$ and Le Gruyère $(\Delta)$.

and Tilsiter show that the concentration of VPP + IPP may decrease during cheese ripening, it is likely that the 2 tripeptides are less susceptible to further degradation than other ACE-inhibiting peptides. As a consequence, the best agreement between ACE inhibition and the concentration of VPP + IPP can be expected at advanced stages of ripening. At early stages of ripening it is difficult to establish a relationship because many other ACE-inhibiting peptides released from $\beta$-casein and $\alpha_{\mathrm{s} 1}$-casein can interfere (Meisel et al., 2006).

\section{CONCLUSIONS}

Inhibition of ACE as well as the concentration of the 2 antihypertensive tripeptides VPP and IPP was monitored in 7 cheese varieties during the usual period of consumption. The best agreement between ACE inhibition and the concentration of VPP + IPP was obtained at advanced stages of ripening probably because of the lower susceptibility of VPP and IPP to further degradation compared with other ACE-inhibiting peptides. The results obtained suggest that qualitative differences in the proteolysis pattern, not quantitative differences in the degree of proteolysis, are responsible for the observed variations in the total concentration of VPP + IPP in individual cheeses of various varieties. In individual cheeses, the presence of Lactobacillus 
helveticus in the starter culture was associated with elevated concentrations of VPP and IPP. Although large variations were obtained among individual loaves from different producers, the results of the present study confirm that concentrations of VPP + IPP $>100$ $\mathrm{mg} / \mathrm{kg}$ are attainable in the investigated semi-hard varieties after ripening periods of about 4 to $7 \mathrm{mo}$ and that stable concentrations of the 2 tripeptides can be expected over several weeks of cheese ripening. Thus, it will be possible to develop functional cheeses that contain similar concentrations of the 2 antihypertensive peptides as found in recently launched sour milks that have been shown to be effective against hypertension with concentrations of VPP + IPP of about $5 \mathrm{mg} / \mathrm{d}$. However, further studies with selected cultures are needed to develop a reproducible cheese-making process that yields cheeses with high concentrations of VPP + IPP that could be used for clinical trials.

\section{ACKNOWLEDGMENTS}

We thank the manufacturers of the Appenzeller 1/4 fat, Tilsiter, Tête de Moine, Vacherin fribourgeois, Berner Hobelkäse, Gruyère, and Emmentaler cheeses and cheese consultants Daniel Goy, Jean-Pierre Häni, Hans Winkler, Ruedi Amrein and Ernst Jakob (Agroscope Liebefeld-Posieux Research Station ALP) for their kind assistance in sampling and providing information on the manufacturing conditions of the investigated cheeses of this study. Furthermore, we thank Andreas Bosshart and Nadine Kaldas (Agroscope Liebefeld-Posieux Research Station ALP) for the accurate determination of ACE inhibition for the careful determination of VPP and IPP in the samples of this study, respectively.

\section{REFERENCES}

Bachmann, H. P., U. Bütikofer, and J. Meyer. 1999. Prediction of flavour and texture development in Swiss-type cheeses. Lebensm. Wiss. Technol. 32:284-289.

Bachmann, H. P., U. Bütikofer, and R. Sieber. 2003. Über das Vorkommen von bioaktiven Peptiden in Käse (On the occurrence of bioactive peptides in cheese). Mitt. Lebensmittelunters. Hyg. 94:136-154.

Bernard, B. K., Y. Nakamura, I. Bando, and J. H. Mennear. 2005. Studies of the toxicological potential of tripeptides (L-valyl-L-prolylL-proline and L-isoleucyl-L-prolyl-L-proline): II. Introduction. Int. J. Toxicol. 24(Suppl. 4):5-11.

Bütikofer, U., E. Baumann, R. Sieber, and J. O. Bosset. 1998. Ripening of Emmental cheese wrapped in foil with and without addition of Lactobacillus casei subsp. casei. IV. HPLC separation of water soluble peptides. Lebensm. Wiss. Technol. 31:297-301.

Bütikofer, U., J. Meyer, R. Sieber, B. Walther, and D. Wechsler. 2008. Occurrence of the angiotensin-converting enzyme-inhibiting tripeptides Val-Pro-Pro and Ile-Pro-Pro in different cheese varieties of Swiss origin. J. Dairy Sci. 91:29-38.

Bütikofer, U., J. Meyer, R. Sieber, and D. Wechsler. 2007. Quantification of the angiotensin-converting enzyme-inhibiting tripeptides Val-
Pro-Pro and Ile-Pro-Pro in hard, semi-hard and soft cheeses. Int. Dairy J. 17:968-975.

Christensen, J. E., E. G. Dudley, J. A. Pederson, and J. L. Steele. 1999. Peptidases and amino acid catabolism in lactic acid bacteria. Antonie Van Leeuwenhoek 76:217-246.

Cushman, D. W., and H. S. Cheung. 1970. Spectrophotometric assay and properties of the angiotensin-converting enzyme of rabbit lung. Biochem. Pharmacol. 20:1637-1648.

Gagnaire, V., D. Mollé, M. Herrouin, and J. Léonil. 2001. Peptides identified during Emmental cheese ripening: Origin and proteolytic systems involved. J. Agric. Food Chem. 49:4402-4413.

Gómez-Ruiz, J. Á., M. Ramos, and I. Recio. 2002. Angiotensinconverting enzyme-inhibitory peptides in Manchego cheeses manufactured with different starter cultures. Int. Dairy J. 12:697-706.

Gómez-Ruiz, J. Á., M. Ramos, and I. Recio. 2004. Identification and formation of angiotensin-converting enzyme-inhibitory peptides in Manchego cheese by high-performance liquid chromatographytandem mass spectrometry. J. Chromatogr. A 1054:269-277.

Gómez-Ruiz, J. Á., G. Taborda, L. Amigo, M. Ramos, and E. Molina. 2007. Sensory and mass spectrometric analysis of the peptidic fraction lower than one thousand daltons in Manchego cheese. J. Dairy Sci. 90:4966-4973.

Gómez-Ruiz, J. Á., G. Taborda, L. Amigo, I. Recio, and M. Ramos. 2006. Identification of ACE-inhibitory peptides in different Spanish cheeses by tandem mass spectrometry. Eur. Food Res. Technol. 223:595-601.

Haileselassie, S. S., B. H. Lee, and B. F. Gibbs. 1999. Purification and identification of potentially bioactive peptides from enzymemodified cheese. J. Dairy Sci. 82:1612-1617.

Haque, E., and R. Chand. 2008. Antihypertensive and antimicrobial bioactive peptides from milk proteins. Eur. Food Res. Technol. 227:7-15.

Hata, Y., M. Yamamoto, M. Ohni, K. Nakajima, Y. Nakamura, and T. Takano. 1996. A placebo-controlled study of the effect of sour milk on blood pressure in hypertensive subjects. Am. J. Clin. Nutr. 64:767-771.

Jakob, E., R. Badertscher, and U. Bütikofer. 2007. Zusammensetzung von Berner Alp- und Hobelkäse (Composition of Bernese Alpine Cheese and Hobelkäse). Agrarforschung 14:96-101.

Jauhiainen, T., H. Vapaatalo, T. Poussa, S. Kyronpalo, M. Rasmussen, and R. Korpela. 2005. Lactobacillus helveticus fermented milk lowers blood pressure in hypertensive subjects in 24-h ambulatory blood pressure measurement. Am. J. Hypertens. 18:1600-1605.

Masuda, O., Y. Nakamura, and T. Takano. 1996. Antihypertensive peptides are present in aorta after oral administration of sour milk containing these peptides to spontaneously hypertensive rats. J. Nutr. 126:3063-3068.

Meisel, H., A. Goepfert, and S. Günther. 1997. ACE-inhibitory activities in milk products. Milchwissenschaft 52:307-311.

Meisel, H., D. J. Walsh, B. Murray, and R. J. FitzGerald. 2006. ACE inhibiting peptides. Pages 269-315 in Nutraceutical Proteins and Peptides in Health and Disease. Y. Mine and F. Shahidi, ed. CRC Press, New York, NY.

Nakamura, Y., N. Yamamoto, K. Sakai, A. Okubo, S. Yamazaki, and T. Takano. 1995a. Purification and characterization of angiotensin I-converting enzyme inhibitors from sour milk. J. Dairy Sci. 78:777-783.

Nakamura, Y., N. Yamamoto, K. Sakai, and T. Takano. 1995b. Antihypertensive effect of sour milk and peptides isolated from it that are inhibitors to angiotensin I-converting enzyme. J. Dairy Sci. $78: 1253-1257$.

Ohsawa, K., H. Satsu, K. Ohki, M. Enjoh, T. Takano, and M. Shimizu. 2008. Producibility and digestibility of antihypertensive $\beta$-casein tripeptides, Val-Pro-Pro and Ile-Pro-Pro, in the gastrointestinal tract: Analyses using an in vitro model of mammalian gastrointestinal digestion. J. Agric. Food Chem. 56:854-858.

Okamoto, A., H. Hanagata, E. Matsumoto, Y. Kawamura, Y. Koizumi, and F. Yanagida. 1995. Angiotensin-converting enzyme inhibitory 
activities of various fermented foods. Biosci. Biotechnol. Biochem. 59:1147-1149.

Ong, L., A. Henriksson, and N. P. Shah. 2007. Angiotensin converting enzyme-inhibitory activity in Cheddar cheeses made with the addition of probiotic Lactobacillus casei $\mathrm{sp}$. Lait 87:149-165.

Ong, L., and N. P. Shah. 2008a. Release and identification of angiotensin converting enzyme-inhibitory peptides as influenced by ripening temperatures and probiotic adjuncts in Cheddar cheeses. Lebensm. Wiss. Technol. 41:1555-1566.

Ong, L., and N. P. Shah. 2008b. Influence of probiotic Lactobacillus acidophilus and L. helveticus on proteolysis, organic acid profiles, and ACE-inhibitory activity of cheddar cheeses ripened at 4, 8, and $12^{\circ} \mathrm{C}$. J. Food Sci. 73:M111-M120.

Parrot, S., P. Degraeve, C. Curia, and A. Martial-Gros. 2003. In vitro study on digestion of peptides in Emmental cheese: Analytical evaluation and influence on angiotensin I converting enzyme inhibitory peptides. Nahrung-Food 47:87-94.

Pripp, A. H., R. Sorensen, L. Stepaniak, and T. Sørhaug. 2006. Relationship between proteolysis and angiotensin-I-converting enzyme inhibition in different cheeses. Lebensm. Wiss. Technol. 39:677-683.

Ryhänen, E. L., A. Pihlanto-Leppälä, and E. Pahkala. 2001. A new type of ripened, low-fat cheese with bioactive properties. Int. Dairy J. 11:441-447.

Saito, T., T. Nakamura, H. Kitazawa, Y. Kawai, and T. Itoh. 2000 Isolation and structural analysis of antihypertensive peptides that exist naturally in Gouda cheese. J. Dairy Sci. 83:1434-1440.

Schär, H., H. Glättli, U. Moor, B. Nick, R. Sieber, and G. Steiger. 1992. Untersuchungen über den Reifungsverlauf von qualitativ gutem Walliser Raclettekäse. (Analyses of Walliser Raclette cheese of good quality during ripening). Schweiz. Milchwirt. Forsch. $21: 52-57$

Seppo, L., T. Jauhiainen, T. Poussa, and R. Korpela. 2003. A fermented milk high in bioactive peptides has a blood pressure-lowering effect in hypertensive subjects. Am. J. Clin. Nutr. 77:326-330.

Seppo, L., O. Kerojoki, T. Suomalainen, and R. Korpela. 2002. The effect of a Lactobacillus helveticus LBK-16 H fermented milk on hypertension-A pilot study on humans. Milchwissenschaft $57: 124-127$.
Silva, S. V., A. Pihlanto, and F. X. Malcata. 2006. Bioactive peptides in ovine and caprine cheeselike systems prepared with proteases from Cynara cardunculus. J. Dairy Sci. 89:3336-3344.

Sipola, M., P. Finckenberg, J. Santisteban, R. Korpela, H. Vapaatalo, and M. L. Nurminen. 2001. Long-term intake of milk peptides attenuates development of hypertension in spontaneously hypertensive rats. J. Physiol. Pharmacol. 52:745-754.

Smacchi, E., and M. Gobbetti. 1998. Peptides from several Italian cheeses inhibitory to proteolytic enzymes of lactic acid bacteria, Pseudomonas fluorescens ATCC 948 and to the angiotensin I-converting enzyme. Enzyme Microb. Technol. 22:687-694.

Sollberger, H., H. Glättli, B. Nick, M. Rüegg, R. Sieber, and G. Steiger. 1991. Untersuchungen über den Reifungsverlauf guter Sbrinzkäse. (Analyses of Sbrinz cheese of good quality during ripening). Schweiz. Milchwirt. Forsch. 20:63-69.

Steffen, C., F. Rentsch, B. Nick, G. Steiger, R. Sieber, H. Glättli, and P. Eberhard. 1992. Reifungsverlauf in qualitativ gutem Gruyère. (Ripening process in Gruyere of good quality). Landwirt. Schweiz 5:209-215.

Steffen, C. H. Schär, P. Eberhard, H. Glättli, B. Nick, F. Rentsch, G. Steiger, and R. Sieber. 1993a. Untersuchungen über den Reifungsverlauf von qualitativ gutem Käse: Tilsiter aus Rohmilch. (Analyses of raw milk Tilsit cheese of good quality during ripening). Schweiz. Milchwirt. Forsch. 21:46-51.

Steffen, C., H. Schär, P. Eberhard, H. Glättli, B. Nick, F. Rentsch, G. Steiger, and R. Sieber. 1993b. Untersuchungen über den Reifungsverlauf von qualitativ gutem Käse: Appenzeller. (Analyses of Appenzell cheese of good quality during ripening). Schweiz. Milchwirt. Forsch. 21:39-45.

Stepaniak, L., L. Jedrychowski, B. Wroblewska, and T. Sørhaug. 2001. Immunoreactivity and inhibition of angiotensin-I converting enzyme and lactococcal oligopeptidase by peptides from cheese. Ital. J. Food Sci. 13:373-381.

Tuomilehto, J., J. Lindström, J. Hyyrynen, R. Korpela, M. L. Karhunen, L. Mikkola, T. Jauhiainen, L. Seppo, and A. Nissinen. 2004. Effect of ingesting sour milk fermented using Lactobacillus helveticus bacteria producing tripeptides on blood pressure in subjects with mild hypertension. J. Hum. Hypertens. 18:795-802. 